\title{
Knowledge and use of edible mushrooms in two municipalities of the Sierra Tarahumara, Chihuahua, Mexico
}

Miroslava Quiñónez-Martínez ${ }^{1 *}$, Felipe Ruan-Soto ${ }^{2}$, Ivonne Estela Aguilar-Moreno ${ }^{1}$, Fortunato Garza-Ocañas ${ }^{3}$, Toutcha Lebgue-Keleng ${ }^{4}$, Pablo Antonio Lavín-Murcio ${ }^{1}$ and Irma Delia Enríquez-Anchondo ${ }^{1}$

\begin{abstract}
Background: The Sierra Madre Occidental of Chihuahua in Northern Mexico is inhabited by indigenous Raramuris, mestizos, and other ethnic groups. The territory consists of canyons and ravines with pine, oak and pine-oak forests in the higher plateaus. A great diversity of potentially edible mushrooms is found in forests of the Municipalities of Bocoyna and Urique. Their residents are the only consumers of wild mushrooms in the Northern Mexico; they have a long tradition of collecting and eating these during the "rainy season." However, despite the wide diversity of edible mushrooms that grow in these areas, residents have a selective preference. This paper aims to record evidence of the knowledge and use of wild potentially edible mushroom species by inhabitants of towns in the Sierra Tarahumara of Chihuahua, Mexico.
\end{abstract}

Method: Using a semi-structured technique, we surveyed 197 habitants from seven locations in Urique, Bocoyna, and the Cusarare area from 2010 to 2012. Known fungi, local nomenclature, species consumed, preparation methods, appreciation of taste, forms of preservation, criteria for differentiating toxic and edible fungi, other uses, economic aspects, and traditional teaching were recorded. To identify the recognized species, photographic stimuli of 22 local edible species and two toxic species were used.

Results: The respondents reported preference for five species: Amanita rubescens, Agaricus campestris, Ustilago maydis, Hypomyces lactifluorum, and the Amanita caesarea complex. No apparent differences were found between ethnic groups in terms of preference, although mestizos used other species in Bocoyna (Boletus edulis and B. pinophilus). Some different uses of fungi are recognized by respondents, i.e. home decorations, medicine, as food in breeding rams, etc.

Conclusion: The studied population shows a great appreciation towards five species, mainly the A. caesarea complex, and an apparent lack of knowledge of nearly 20 species which are used as food in other areas of Mexico. There are no apparent differences among Sierra inhabitants in terms of gender, occupation, or language regarding the recognition and consumption of species. The rejection of certain species is due mainly to fear of poisoning and the traditional selective teaching of families in the mountain communities of the Sierra Tarahumara.

Keywords: Wild edible mushrooms, Mestizos, Raramuris, Forest, Chihuahua

\footnotetext{
* Correspondence: mquinone@uacj.mx

${ }^{1}$ Instituto de Ciencias Biomédicas, Universidad Autónoma de Ciudad Juárez,

Ciudad Juárez, Chihuahua, México

Full list of author information is available at the end of the article
} 


\section{Background}

Chihuahua is the largest state in Mexico. It comprises $12.6 \%$ of the country's area [1]. The southwestern portion of the Sierra Madre Occidental in this state is known as Sierra Tarahumara for it is occupied by an ethnic group known as the Raramuri or Tarahumara (Figure 1), which means "light footed people". Even though the Raramuris represent the largest group in the area, other ethnic groups such as the Tepehuanos or Odame; the Guarojios, or Guarijo; the Pimas; and numerous other mountain mestizos called "Chabochi" or "Yori" [2-4] inhabit the region, and all together they comprise a population of approximately 270,000 people [1]. The main activities that sustain them are: forest logging, mining, trade, small-scale seasonal agriculture, agro-pastoralism, and artisanal production [5], where the later three meet the needs of Raramuris [6].

The territory that forms the Sierra Tarahumara consists of canyons and ravines where plant communities in the higher plateaus are pine, oak, and pine-oak forests [7] (Figure 2). Total annual precipitation ranges from 600 to $1200 \mathrm{~mm}$, with an annual average of $705 \mathrm{~mm}$. There is a well-defined season during the months of July to September which accounts for $68 \%$ of total precipitation [8]. Those forests harbor a variety of macroscopic fungi $[9,10]$, and some of them recognized by the villagers as food and are consumed during the rainy season [11].

Wild mushrooms are a non-timber forest resource valued by mycophilic human populations around the world [12-14]; their use has been recorded in many countries, and they are exploited commercially as food or medicine $[15,16]$. Recent studies (within the last 10 years) are scarce in the state of Chihuahua [17-20]. Moreno et al. [21] mentioned that there are about 450 species studied so far, and this number is considered low due to the magnitude of the ecological diversity and size of the region. This positions the Sierra Tarahumara as a region with a great richness

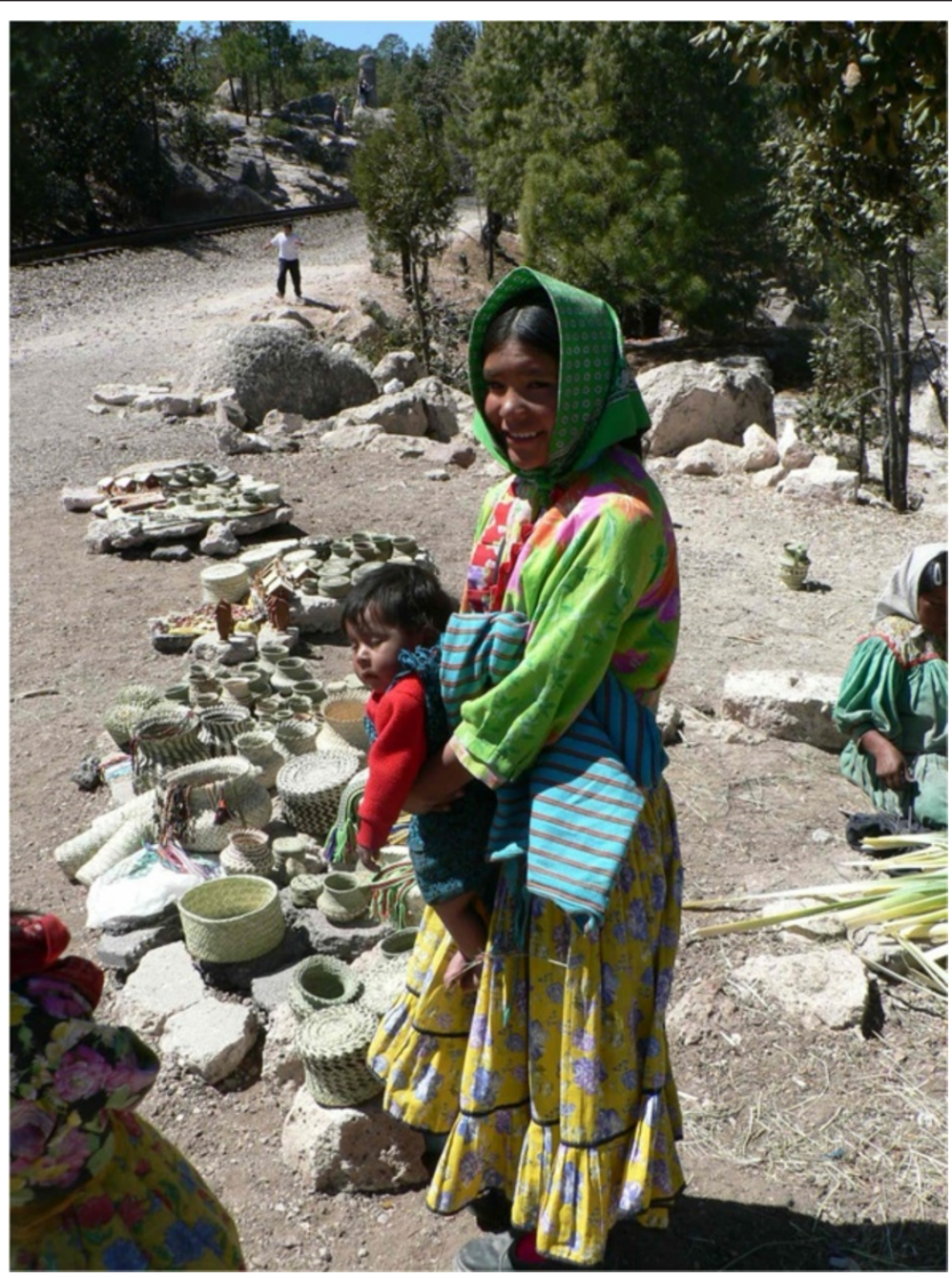

Figure 1 Raramuri girl selling palm crafts in the Sierra Tarahumara. 


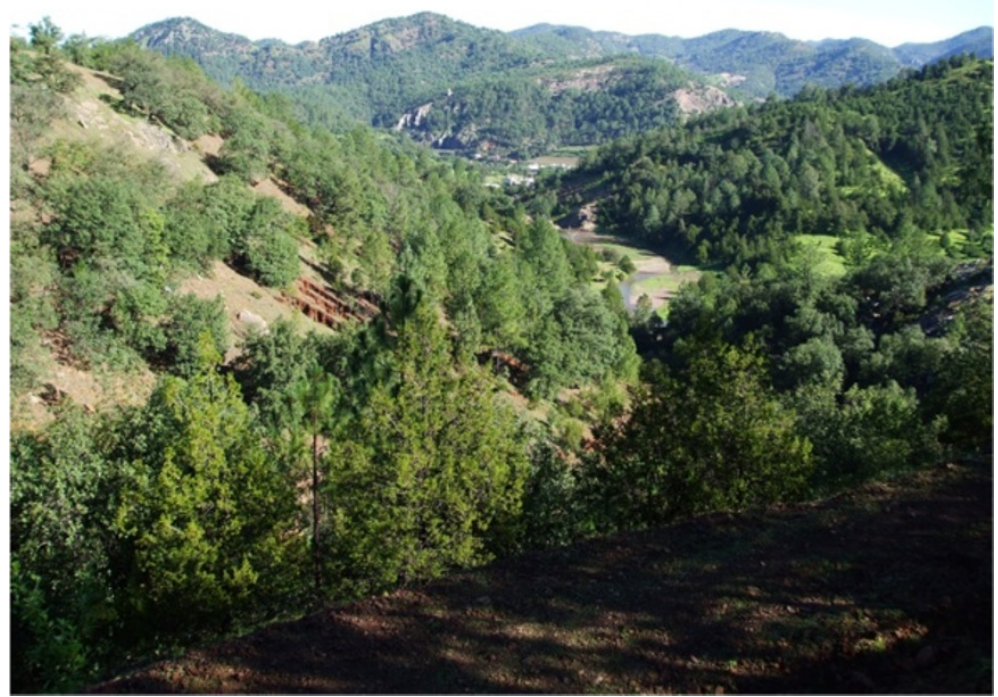

Figure $\mathbf{2}$ Landscape forest vegetation of the Sierra Tarahumara.

and diversity of fungi within an important and rich culture inhabited by indigenous and mestizo people. However, due to the orographic conditions, which make it difficult to reach, plus the isolated way of living of the Raramuris, this region is one of the least studied as far as mycocultural patrimony is concerned [3]. There are only a few studies that document ethnomycological data in the region [22-24]. In 2002, Moreno [25] conducted a study, specifically in two Raramuri populations (Panalachi and Tónachi) isolated from the influence of the mestizos, reporting 22 taxa with local ethnomycological importance. In a study conducted in the coniferous forest of the Sierra Tarahumara, Quiñonez et al. [26] reported a list of 50 wild mushrooms considered by the literature as potentially edible [27-29], including the results of a pilot survey on the potential use of some species by 50 people from the town of San Juanito, Chihuahua, highlighting the Amanita caesarea complex as the most consumed mushroom [26]. Other studies in different parts of Mexico showed that wild mushroom consumption is not standard nor generalized in the country, meaning that people tend to consider them to a lesser extent as a reliable food source [30-32]. Fear of poisoning and potential mortality associated with mushroom consumption [11,31,32] could be the possible causes linked to the low use of the fungal resources in the area, a fact that was highlighted by different researchers in the country [33].

Therefore, the objective of this study was to register and systematize the knowledge and use of the edible mushrooms in some parts of the Sierra Taharumara and hence contribute to the documentation of a biocultural patrimony in the least studied regions of Mexico.

\section{Methods}

\section{Study area}

The study was conducted in the localities of: San Juanito, Bocoyna, Arareco, and Creel in the municipality of Bocoyna; Pitorreal, El Divisadero, and San Rafael belonging to the municipality of Urique; and at the Cusarare waterfall in the municipality of Guachochi in the state of Chihuahua (Figure 3).

San Juanito, Bocoyna, Arareco, and Creel are located in the upper part of the Sierra Madre Occidental at $220 \mathrm{~km}$ southwest of the city of Chihuahua, at $27^{\circ} 30^{\prime}$ and $28^{\circ} 30^{\prime}$ latitude north and between $107^{\circ} 00^{\prime}$ and $108^{\circ}$ $00^{\prime}$ longitude west. They have an average altitude of 2,350 meters with a maximum of $3,400 \mathrm{~m}$. In general, the vegetation communities are made up of pine forest $(\mathrm{P})$, pine-oak forest $(\mathrm{Pq})$, oak-pine forest $(\mathrm{Qp})$ and chaparral. There are areas with steep slopes with the presence of shallow soils belonging to the groups of Ferozems and Lithosols, characterized by a thin horizon layer containing little organic matter (humus) and some areas with deep soils used as agricultural lands [8]. The municipality of Bocoyna has a total of 505 villages with 28,766 inhabitants. Two urban areas are considered to have high number of inhabitants: San Juanito has 10,535 inhabitants, of which 152 are speakers of indigenous languages and Creel has 5,026 inhabitants with 350 Raramuris (the rest considered mestizos). The main activities of the inhabitants are local commerce, forestry, and tourism [34,35]. Pitorreal, El Divisadero, and San Rafael in the municipality of Urique have an average altitude of 2,120 meters, with a maximum of 2,299 $\mathrm{m}$ and are located geographically between $27^{\circ} 29^{\prime}$ 


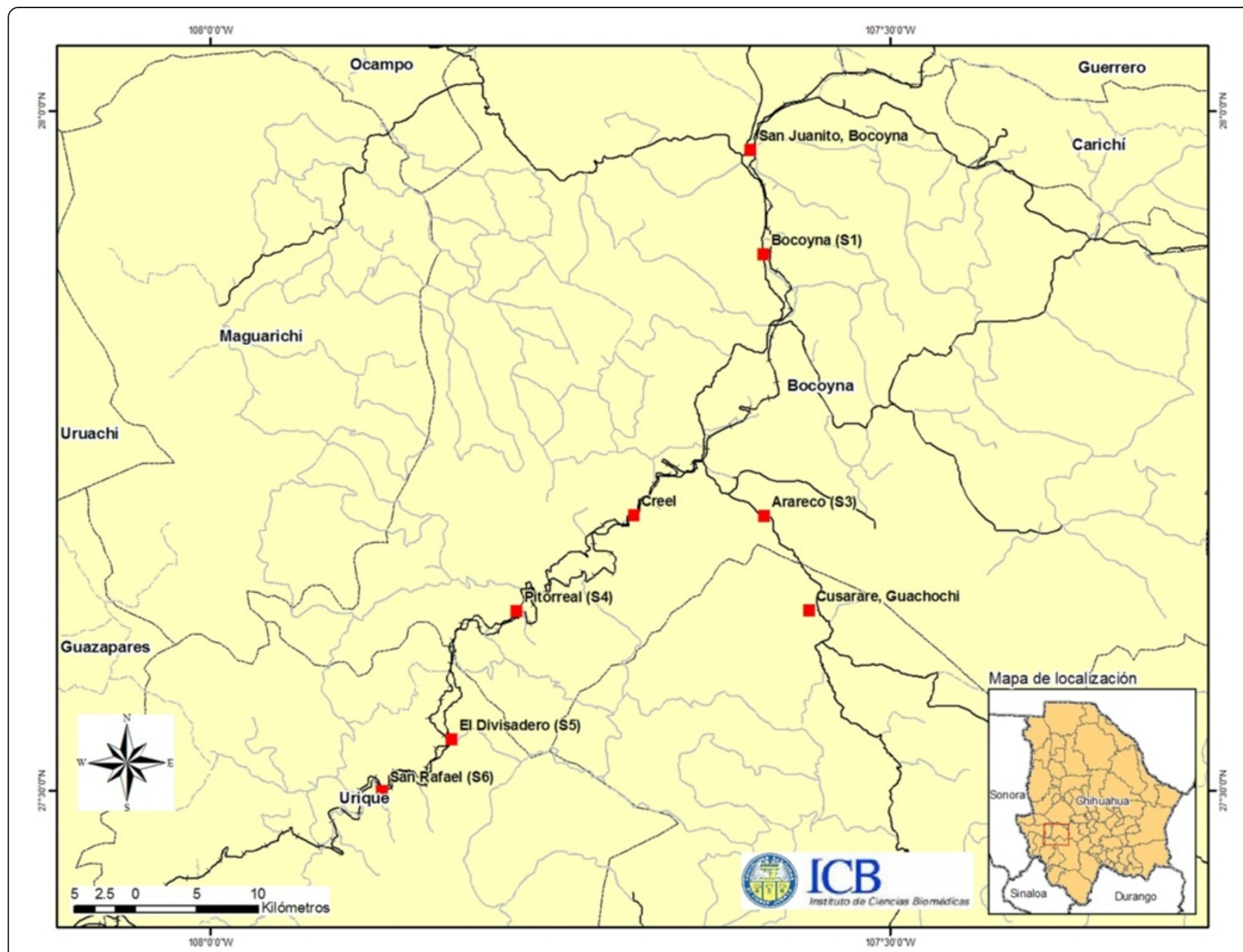

Figure 3 Location of the study area.

and $27^{\circ} 37^{\prime}$ latitude north, and $107^{\circ} 52^{\prime}$ to $107^{\circ} 46^{\prime}$ longitude west. The higher vegetation layer of these forests is formed mainly by the pine species: Pinus arizonica, $P$. engelmannii, $P$. durangensis, and P. leiophylla associated with oak species, mainly Quercus arizonica, Q. chihuahuensis, Q. jonesii, Q. mcvaughii, Q. crassifolia, Q. depressipes, Q. durifolia, and $Q$. hypoleucoides. Their combination forms plant communities of pine-oak forest $(\mathrm{Pq})$ and oak-pine forest $(\mathrm{Qp})$ [36,37]. According to the National Institute of Statistics and Geography (INEGI), Pitorreal has a population of 14 inhabitants, El Divisadero11, and San Rafael 2,160 and the latter considered one the most important towns for being the most populous of the Municipality of Urique. The number of indigenous speakers in this location is 369 . The main economic activities are forestry, tourism, and commerce [35].

The Cusarare waterfall, in the municipality of Guachochi, is located $25 \mathrm{~km}$ southeast of Creel, Chihuahua. It has a fall of $30 \mathrm{~m}$ during the months of July to October, and the surrounding vegetation is made up of pine forest. This waterfall is one of the main tourist attractions and sources of income for some residents in the area, mainly the ethnic Raramuri group [38]. The area of Cusarare has 106 inhabitants, and 19 of them are native speakers [35]. All sites are characterized by the sale of handicrafts made by both indigenous and mestizo people, which they sell to domestic and foreign tourists visiting the tourist sites and towns in Bocoyna and Urique, mainly El Divisadero, Barrancas, and Creel.

\section{Ethnomycological study}

A study on fungal consumption and use by the inhabitants of several communities was conducted from 2010 to 2012. Before starting work, permission was requested of the civil authorities of the municipalities in order to carry out the study. In addition, each person interviewed was asked verbally for his/her consent and was informed that the data would be used for the present study. Semistructured interviews as proposed by Bernard [39] were given to 197 people in the study area (Table 1 ).

All respondents were asked if they were willing to be interviewed about their knowledge and use of wild 
Table 1 Localities of the interviewed people of the Sierra Tarahumara

\begin{tabular}{ll}
\hline Localities & $\mathbf{n}(\%)$ \\
\hline San Juanito & $65(33)$ \\
Creel & $48(24)$ \\
San Rafael & $30(15)$ \\
El Divisadero & $14(7)$ \\
Pitorreal & $11(6)$ \\
Bocoyna & $11(6)$ \\
Cusarare & $11(6)$ \\
Arareco & $7(4)$ \\
\hline
\end{tabular}

mushrooms growing in the region where they live, informing them previously of the objectives of the study and that if they decided to participate, their answers would be used for a scientific publication. Only those who gave their express informed consent were subsequently interviewed, respecting the decision of those who refused to participate in the investigation. The study was approved by the Research Ethics Committee of University Autonomy of Ciudad Juárez(CBE.ICB/20.08-14).

From each interviewed person, the following information was obtained: known fungi, local nomenclature, species consumed, preparation methods, appreciation of taste, forms of preservation, criteria for differentiating toxic and edible fungi, other uses, economic aspects, and ways of knowledge transmission. Also included were questions on sociodemographic information such as age, gender, occupation and ethnicity (Raramuris or mestizos). For the semi-structured interviews, pre-established formats were used (Additional file 1: Annex). To identify the species recognized by respondents, photographic stimuli of 22 edible species that commonly grow in the Sierra Tarahumara plus two toxic species were used: 1. Amanita caesarea complex; 2. A. rubescens Pers; 3. Hypomyces lactifluorum Schwein. Tul \& C.Tul; 4. Russula brevipes Peck; 5. Boletus chrysenteron Bull; 6. Laccaria laccata (Scop.) Cooke; 7. Boletus pinophilus Pilat \& Dermek; 8. Boletus edulis Bull; 9. Cantharellus cibarius Fr; 10. Lactarius deliciosus (L.) Gray; 11. Auricularia polytricha (Mont.) Sacc; 12. Coprinus comatus O. F. (Müll.) Pers; 13. Ramaria aff. flava Quél; 14. Morchella vulgaris (Pers.) Boudier; 15. Hericium erinaceus (Bull.) Persoon; 16. Lactarius indigo (Schwein.) Fr; 17. Agaricus campestris L.: Fr.; 18. Boletellus russellii (Frost) Gilbert; 19. Helvella crispa Bull; 20. Schizophyllum commune Fr; 21. Ustilago maydis (DC.) Corda; 22. Helvella lacunosa Afzel; 23. Amanita muscaria (L:Fr.) Lam, and 24. Amanita virosa (Fr.) Bertill (Figures 4 and 5). These species were selected for references of records and abundant growth and for being common in these forest soils $[10,36]$. For the stimuli, the technique proposed by Thomas [40] was taken into account. Besides these photographic stimuli, in so far as possible, fresh mushrooms were used for correlation with the taxonomic fungi mentioned in the interviews. The collected samples were described in terms of macroscopic characteristics and were photographed and classified according to the [41] proposed by Cifuentes et al. Subsequently the specimens were reviewed microscopically following conventional mycological techniques [42]. Specialized taxonomic keys were used to determine the different specimens. Finally, these were deposited in the Biodiversity Herbarium of the Institute of Biomedical Sciences of the Autonomous University of Ciudad Juarez. Qualitative analysis of the information obtained

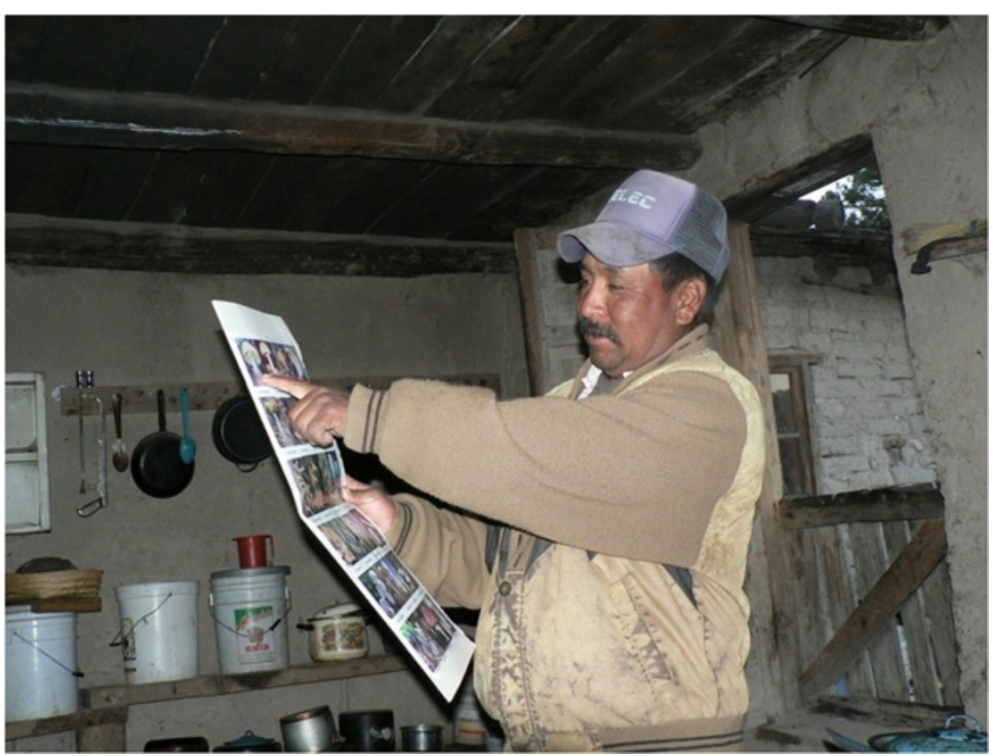

Figure $4 \mathrm{~A}$ resident of the Sierra Tarahumara indicating the photograph of his mushroom of choice. 


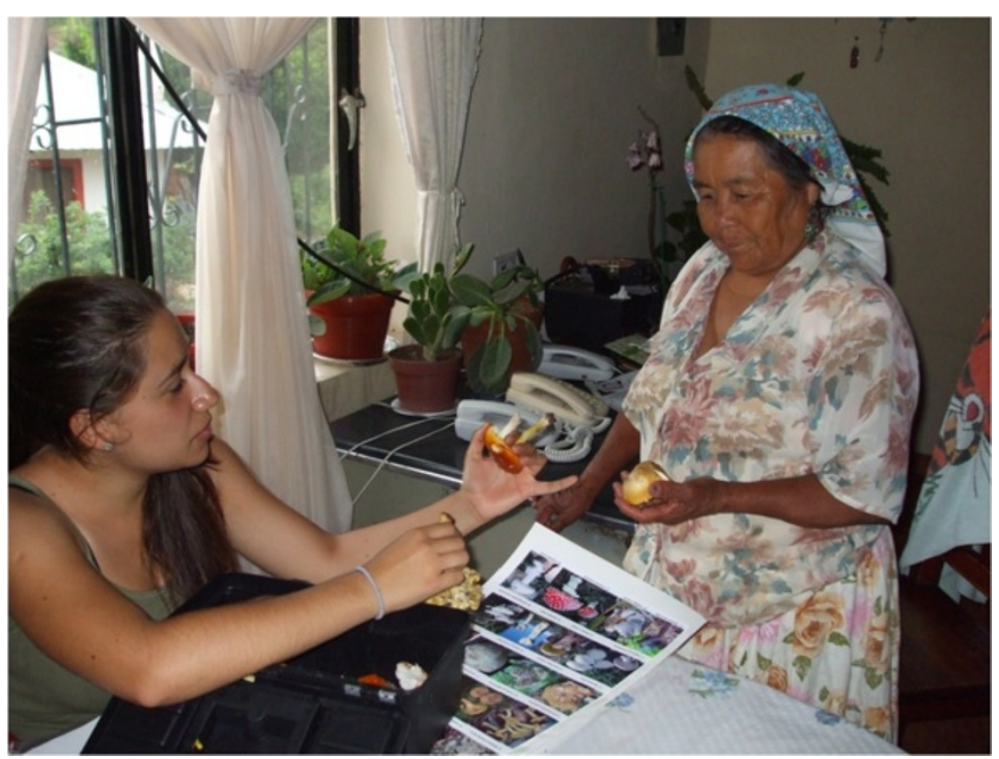

Figure 5 Interview with a housewife showing fresh mushrooms and wild mushrooms of the Sierra Tarahumara.

was performed through constant comparison of categories according to the analysis proposed by Sandoval [43]. The names of fungi in Raramuri were written and verified by an expert in the Raramuri language working in the Language Center of the Autonomous University of Ciudad Juarez.

\section{Results and discussion}

\section{Overview of the interviewed population}

Of the 197 respondents, 30\% were retailers (mainly groceries, fruit, vegetables, meats, and basic household products) and all of them were mestizo, 19.2\% were students (mainly from the elementary and secondary level), 9.13\% were housewives, $3.5 \%$ were professionals from fields such as medicine, nursing, nutrition, law enforcement, and accounting (with one to two respondents per each field); $29.4 \%$ were from diverse occupations such as farmers, artisans, mill workers, auto mechanics, construction workers, drivers, servants (Table 2); and the rest did not want to

Table 2 Occupation, gender, and ethnicity of the interviewed population $(n=197)$

\begin{tabular}{llllll}
\hline Activities & $\mathbf{n}(\%)$ & Gender & $\mathbf{n}(\%)$ & Ethnic group & $\mathbf{n}(\%)$ \\
\hline Retailers & $61(30.9)$ & Female & $110(56)$ & Mestizo & $146(74)$ \\
Students & $38(19.2)$ & Male & $87(44)$ & Raramuri & $51(26)$ \\
Diverse & $58(29.4)$ & & & \\
Occupations & & & & \\
Professionals & $7(3.55)$ & & & \\
Housewives & $18(9.13)$ & & & \\
Not disclosed & $15(7.61)$ & & & \\
\hline
\end{tabular}

disclose their occupation (7.61\%). From this population, 146 (74\%) people were mestizo or "chabochi" (a term given to people who do not belong to the ethnic Raramuri), and 51 (26\%) were Raramuris. Regarding gender classification, $56 \%$ of the surveyed sample was female $(n=110)$ and $44 \%$ was male $(n=87)$. In addition, ages ranged from 8 to 60 years old, although most of the respondents were between from 25 and 45 years old.

\section{Recognized species}

The results of the interviews from the inhabitants of the eight villages of the municipalities of Bocoyna, Urique, and Guachochi showed that the 24 species were known to the interviewees. Amanita caesarea complex, A. muscaria, and $A$. rubescens turned out to be the species most people recognized, being identified by $92 \%, 84 \%$, and $78 \%$, respectively, of the total population surveyed (Table 3). More than 50 inhabitants recognized five species: $A$. campestris, and $U$. maydis plus the above three; 30 to 40 people recognized Boletus edulis, B. pinophilus and $A$. virosa; and the remaining 16 species were recognized by less than 24 of the inhabitants interviewed (Table 3). No apparent differences were found among people of different gender or speakers of different languages. Species recognition ranged from one to six among women, men, mestizo, and Raramuri people. Only one mestizo, in the town of Creel, recognized 23 species.

\section{Frequency of consumption of edible species}

Of the 22 species used as stimuli, the interviewed population consumed only 16; the remaining six species, although edibility is recognized, were not consumed. Amanita caesarea complex was consumed by $83 \%$ of respondents, and 
Table 3 Frequency of recognition and use of species of edible mushrooms ( $N=197$ people)

\begin{tabular}{lcc}
\hline Species & n (knowledge) & n (use) \\
\hline Amanita caesarea complex & 182 & 164 \\
Amanita muscaria (L.Fr.) Lam & 165 & 0 \\
Amanita rubescens Pers & 153 & 89 \\
Ustilago maydis (DC.) Corda & 63 & 34 \\
Agaricus campestris L.: Fr. & 57 & 30 \\
Boletus pinophilus L.: Fr. & 40 & 14 \\
Amanita virosa (Fr.) Bertill & 32 & 0 \\
Boletus edulis Bull & 30 & 10 \\
Cantharellus cibarius Fr. & 23 & 6 \\
Russula brevipes Peck & 18 & 3 \\
Hypomyces lactifluorum Schwein. Tul \& C.Tul & 17 & 5 \\
Lactarius deliciosus (L.) Gray & 14 & 5 \\
Hericium erinaceus (Bull.) Persoon & 14 & 0 \\
Schizophyllum commune Fr. & 14 & 1 \\
Auricularia polytricha (Mont.) Sacc. & 12 & 1 \\
Ramaria aff. flava Quél. & 10 & 3 \\
Laccaria laccata (Scop.) Cooke & 9 & 1 \\
Boletus chrysenteron Bull. & 8 & 0 \\
Lactarius indigo (Schwein.) Fr. & 8 & 0 \\
Boletellus russellii (Frost) Gilbert & 8 & 0 \\
Coprinus comatus O. F. (Müll.) Pers & 7 & 1 \\
Helvella lacunosa Afzel & 7 & 0 \\
Helvella crispa Bull & 6 & 3 \\
Morchella vulgaris (Pers.) Boudier & & 0 \\
\hline & & \\
& &
\end{tabular}

A. rubescens by $45 \%$. In lower proportion $U$. maydis and A. campestris were consumed by $17 \%$ and $15 \%$, respectively, and 10 to $14 \%$ of the respondents liked B. pinophilus and B. edulis (mostly by people living in the town of San Juanito) these were identified by their spongy texture known as "Boletus", sponge, or "father's cap". Only one man, 72 years of age, and living in the town of San Juanito mentioned that he consumed seven species of fungi, and 36 of the interviewed people consumed only one species, specifically $A$. caesarea complex. Nine of the respondents did not consume fungi; mainly for fear of poisoning because they were aware of deaths of people caused by fungi elsewhere, or simply they did not like their taste or appearance. Most of these people were from San Rafael, Urique (Table 3). Men as well as women consumed on average, two species of mushrooms (with five to seven as the maximum and one as the minimum). This same pattern was found with the mestizos and Raramuris, and the same applied within their different occupations. These results indicated that knowledge of and use made by most mestizos and Raramuris of the middle and top of the Sierra Tarahumara were related to two particular species: $A$. rubescens and $A$. caesarea complex and, to a lesser extent, $A$. campestris. These results coincide in large part with the work of Moreno [25], who performed a similar study in other towns in the Sierra Tarahumara, but specifically with indigenous Raramuri, and concluded that these species were known and consumed. So, regardless of ethnicity, by far these species were the most appreciated in the forests of Chihuahua, with differences in terminology or common names (Table 4). However, this is not the case in all the populations where mushrooms are consumed in Mexico. Some ethnic groups were more similar in their use of certain edible species according to the geographical regions and vegetation types they inhabited [25,44]. For example, studies by Garibay et al. [45] referred to Cantharellus cibarius, as the most frequently consumed species by the Zapotec people from

Table 4 Common designations by mestizos and Raramuris of some wild edible mushrooms of the Sierra Tarahumara (*Raramuri Language; **Nahuatl Name; ${ }^{1}$ Local Names)

\begin{tabular}{|c|c|}
\hline Specie & Common allocations \\
\hline Amanita caesarea complex & $\begin{array}{l}\text { *Morochike, }{ }^{*} \text { Morochic, *Morochiki, } \\
{ }^{*} \text { *Wicowi., }{ }^{*} \text { Amarillo (Yellow), 'Árbol del } \\
\text { hongo (Tree fungus), 'Faldita amarilla } \\
\text { (Yellow skirt), 'Vestidito amarillo (Yellow } \\
\text { dress), ' 'Hongo del agua (Water fungus) }\end{array}$ \\
\hline Amanita rubescens & $\begin{array}{l}\text { *Sojáchic, *Sojáchi, *Serochi, *Sokowekeri, } \\
\text { 'Hongo del agua (Water fungus) }\end{array}$ \\
\hline Hypomyces lactifluorum & $\begin{array}{l}{ }^{1} \text { Trompa de cochi (Pig trunk), *Sokowekeri, } \\
{ }^{1} \text { Trompa (Horn) }\end{array}$ \\
\hline Russula brevipes & 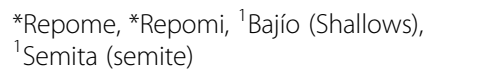 \\
\hline Laccaria laccata & ${ }^{*}$ Longongo \\
\hline Boletus pinophilus & $\begin{array}{l}\text { *Serochako, }{ }^{1} \text { Esponja (Sponge), }{ }^{1} \text { Gorro del } \\
\text { padre (Father's bonnet) }\end{array}$ \\
\hline Boletus edulis & $\begin{array}{l}\text { *Serochako, 'Esponja (Sponge), *Sonaka, } \\
{ }^{1} \text { Gorro del padre (Father's bonnet), } \\
{ }^{1} \text { Panadero (Baker) }\end{array}$ \\
\hline Auricularia polytricha & ${ }^{1}$ Orejona (Big ears) \\
\hline Ramaria aff. flava & ${ }^{1}$ Cola de vaca (Tail of cow) \\
\hline Hericium erinaceus & ${ }^{*}$ Cha'merówa \\
\hline Lactarius indigo & ${ }^{*}$ Cuauhmiqui \\
\hline Agaricus campestris & $\begin{array}{l}{ }^{1} \text { Champiñón (Champignon), ' Hongo del } \\
\text { prado (Fungi of lowland), 'Hongo del llano } \\
\text { (Fungi of grass), 'Del monte (Of mount), } \\
\text { *Wecowique, 'Llanero (Ranger), *Wecowi }\end{array}$ \\
\hline Schizophyllum commune & $\begin{array}{l}{ }^{1} \text { Hongo de la madera (Fungi of the timber), } \\
{ }^{*} \text { Amuri, *Pim de amuri }\end{array}$ \\
\hline Ustilago maydis & $\begin{array}{l}\text { **Huitlacoche, Hongo del maíz (Corn's } \\
\text { fungi), "witachori }\end{array}$ \\
\hline Amanita muscaria & $\begin{array}{l}\text { *Guerechaka, }{ }^{*} \text { Gerechaka, }{ }^{1} \text { Hongo malo } \\
\text { (Bad fungi), }{ }^{1} \text { rojo (red) }\end{array}$ \\
\hline Amanita virosa & $\begin{array}{l}\text { *Kokohurcobi, 'Ángel malo (Bad angel), } \\
\text { 'Ángel venenoso (Poisonous angel) }\end{array}$ \\
\hline
\end{tabular}


Oaxaca, Mexico, but also they mentioned the complex of $A$. caesarea as the most economically important. Grajales-Vasquez et al. [46] reported the preference of edible species in the town of Independence in the state of Chiapas, which included species of such genera as: Pleurotus, Polyporus, and Favolus, (commonly found in tropical areas), but they also recorded $A$. caesarea complex and $C$. cibarius for the higher temperate zones. In an ethnomycology study in two communities in the Lacandon rainforest in Chiapas, Mexico, Ruan-Soto et al. [47] mentioned the use of 10 species of fungi, including nine lignicolous that, according to the perception of respondents, grow on wood and are edible. In this study, Schizophyllum commune was the most known and consumed by the people interviewed in both communities, and it may be considered by the authors as possibly the most prized edible mushroom in the tropical areas of the world [47]. This fungus commonly grows on the trunks of the oaks in the middle and lower parts of the Sierra Tarahumara [20]. In our study, only one person mentioned it as edible, and in Moreno's study [25], it was not mentioned as being used by the Raramuris. More than 50 species of potentially edible wild fungi grow in these forests [9,10,21,26,48]. Within the few species that are consumed, A. rubescens was considered the second option during the month of August, and those who used it stated that it should always be well cooked and never eaten raw. Its use was mainly due to the high competition among the population in the search for and collection of $A$. caesarea complex. In contrast to these results, in other states in Mexico a lot of wild species are consumed on a regular basis, for example, in the villages around the volcano La Malinche, Tlaxcala, people regularly consume 74 different mushrooms, and 73 are regularly consumed in Michoacan state. Mestizos of Ozumba in the state of Mexico consume 89 species, the Nahuas of Tlaxcala 66, the mestizos of Federal District 60, the mestizos of the state of Mexico 56, the Purepecha of Michoacan 56, the Ixtlan Zapotec of Oaxaca 33, and the Nahua of Puebla 28 [49]. In total, in the country there are more than 350 species of wild edible fungi [50].

\section{Culinary information and recognition criteria of edible species}

Amanita rubescens, known as "Sojachi," is consumed after the cuticle of the pileus is removed and is then washed and cooked with tomato, onion, and garlic. Hypomyces lactifluorum ("cochi Trunk") usually has a lot of dirt on it, and should be cleaned and washed several times. Amanita caesarea complex (called "Morochike" or "yellow skirt" or just "yellow") is cut into pieces and cooked with meat or vegetables and typical spices of Mexico like: chili, "tortillas, corn, beans, and "nopal or as part of common dishes like *pozole ("common names of Mexican foods) or cooked with lard (animal fat) and accompanied by beans. Some people from
San Juanito, Arareco and San Rafael claim to wash them in hot water and leave them soaking in water to remove any "hazard" they might carry. They cooked them with garlic in order to test whether they are toxic, using as an indicator a change to black color, indicating that they are poisonous and should not be eaten. This is a common practice throughout the country [50]. However this is not a safe practice as many poisonous mushrooms will react one way or another with the garlic. Also, they admitted that many of the fungi shown in photographs are considered edible elsewhere but they prefer not to eat them for fear, and because they were traditionally considered as bad options. This is a common phenomenon in respect to the utilization of fungi. Moreno Fuentes [25] reported that in another area of the Sierra Tarahumara, the Raramuri did not consume the different species of the genera Boletus, Lactarius, or Russula, which are widely and frequently consumed elsewhere in the country. They prefer to consume only Morochike, Sojachi, and Llanero. In the Arareco area, two people mentioned that they use Pleurotus aff. ostreatus as food and call it Floera, "Amuri" or "Amuri Pin". Some people eat Ramaria and they recognize $R$. aff. flava and call it "cow tail" (Table 4).

\section{Recorded other uses}

Some housewives of San Juanito, mentioned the use of Amanita caesarea complex, $H$. lactifluorum, and $A$. muscaria as home decorations and mentioned using dried Helvella crispa to make necklaces. Some people of Pitorreal mentioned that Laccaria laccata is used medicinally but without specifying the practical use (Table 4). One relevant comment regarding alternative use was for a species of the genus Lycoperdon used by a Raramuri of El Divisadero for the medicinal purpose of removing skin warts by placing the inner opening of the fungus on the face. Another farmer mentioned that he used Boletus edulis and B. pinophilus as food in breeding rams. This use as a forage species is not very common. Ruan-Soto [49] reported the same use of Russula sp. for feeding sheep in the highlands of Chiapas in southern Mexico.

\section{Storage of edible fungi}

Forty nine percent of the interviewed (including Raramuris) said that they do not store the mushrooms - they are usually consumed immediately after collecting or buying them; $17 \%$ reported that they stored the mushrooms dry; $18 \%$ made syrup out of them; and $6 \%$ and $10 \%$ froze or canned them, respectively (Figure 6). Unlike Mestizos of the Sierra Tarahumara, Raramuris use the term "pass," which means dehydrating or drying in soil naturally [25]. In general, preservation techniques are not widespread in the rest of the country, although there are some examples of these practices [44] in the center of the country. 


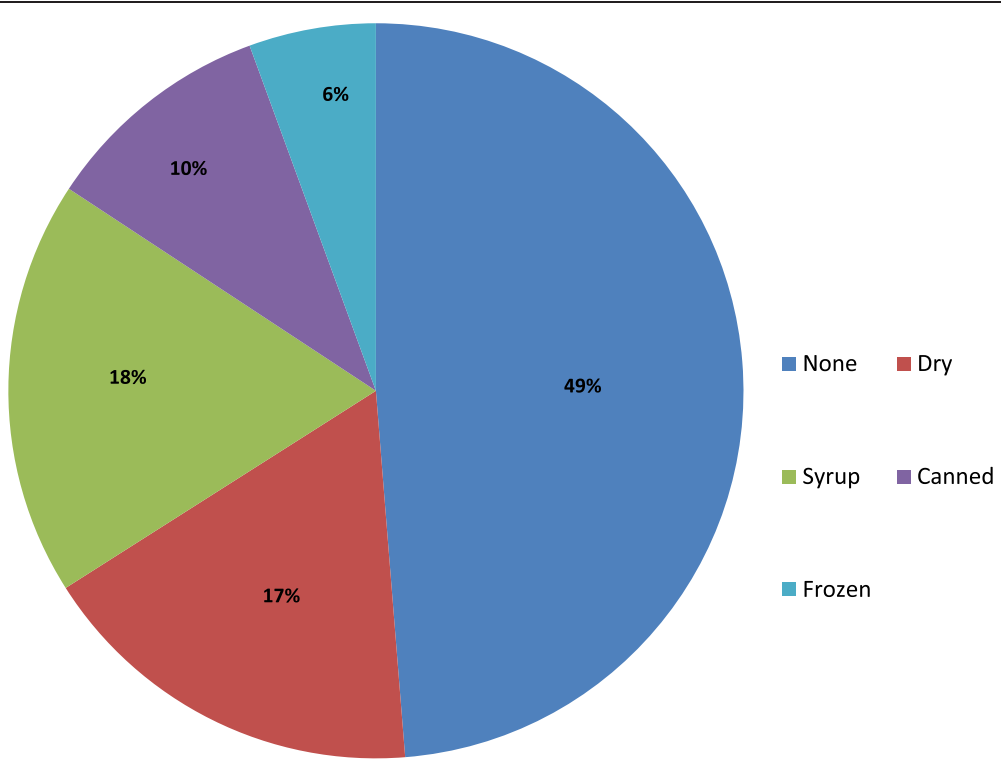

Figure 6 Storage of edible fungi.

\section{Ways of obtaining fungi}

Forty eight percent collect mushrooms directly from the field or forest areas. Forty two percent of the population surveyed reported that they buy their mushrooms from the Raramuris who sell them on the road sides, but sometimes they buy them at their home as a result of door to door to selling. Seven percent mentioned that "Fungus Fair," which is carried out every year in the month of August provides them with a good opportunity to buy mushrooms and reassures them they are edible (Figure 7). This Fair is an event that has been taking place since 1999 during the first week of August in the town of San Juanito, in the municipality of Bocoyna, with the purpose of spreading [21,51] the richness of the edible fungal species that grow in the forest areas surrounding the town through means of conferences, gastronomical contests, fungal picking trips, and exhibition of different species. Three percent mentioned that besides selling, people teach other people how to handle mushrooms in the place known as The Valley of the Mushrooms near Arareco Lake [52].

The Valley of the Mushrooms is an alpine landscape with rock formations similar to the form of the mushrooms, thus the denomination (Figure 8). People living there are indigenous Raramuris subsisting on agriculture (mainly corn) and, because it is a tourist area, women engage in the selling of handicrafts such as palm baskets of different shapes and woven shawls. In the rainy season, from July to September mainly, they collect and sell Morochike (the common name for $A$. caesarea complex by the people of

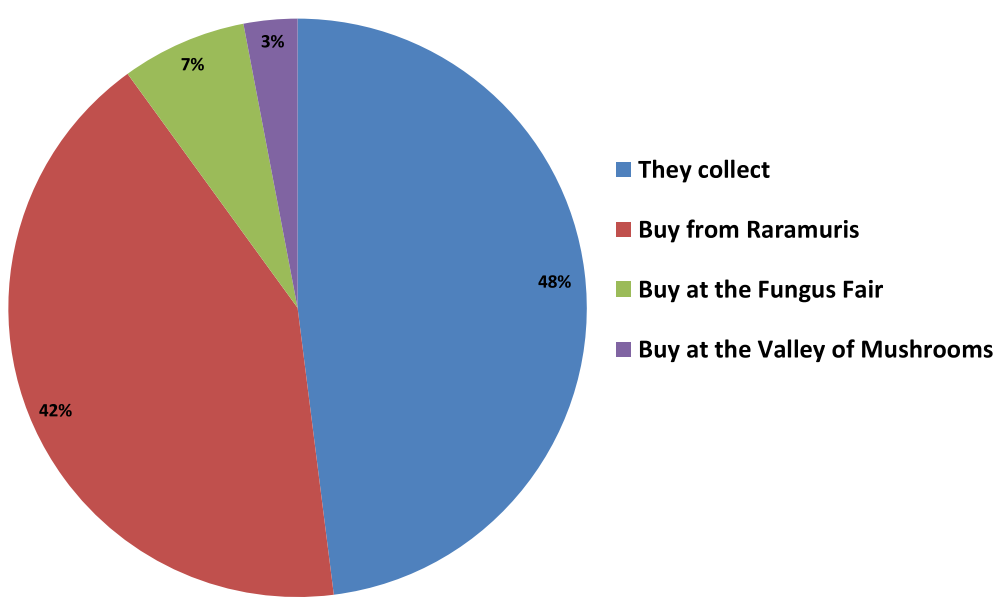

Figure 7 Ways of obtaining fungi. 


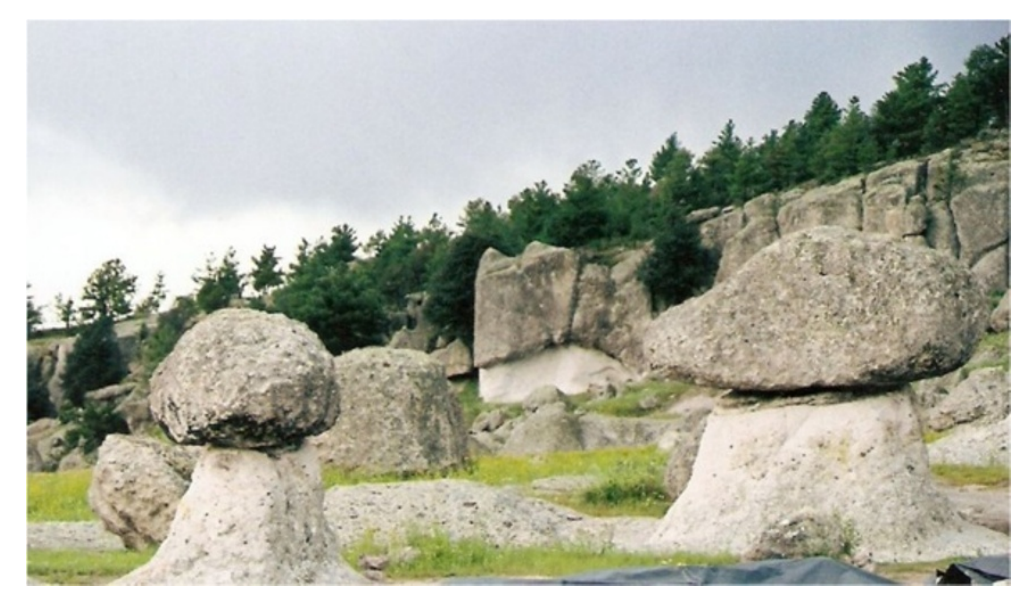

Figure 8 The valley of the mushrooms.

Bocoyna). It is usually sold with the short stem - that is, they refrain from collecting the volva and the base of the stalk, alleging that they are leaving the "seed" to grow back in the next season.

The results of the interviews, as well as of direct observation were carried out in the forests of the Bocoyna and Urique municipalities; these results showed that in the months of June and July, after the arrival of the first rains, many of the farmers and villagers near San Juanito collect and sell mainly two species: A. campestris and Agaricus $s p$. These species are offered along the roads near San Juanito, locally known as mushrooms or wecowi (Figure 9). In August, $A$. caesarea complex and $A$. rubescens are more abundant and are sold on trays or in baskets of different sizes, with the price ranging from $\$ 50.00$ to $\$ 80.00$ pesos according to volume (Figure 10), regardless of the species; although, according to the results obtained, A. caesarea complex is the most valued species by the people of all the villages studied (Table 3). In other states of Mexico, like in Chiapas in the markets of San Cristobal de Las Casas, at least six species of wild mushrooms, especially Amanita jaksonii and $A$. hayalyuy, due to the appreciation that people have for them and taking into account the quantity sold, these can reach up to $\$ 50.00$ pesos per unit (three or four medium-sized mushrooms) [33].

\section{Teaching}

Sixty-six percent of those interviewed reported that they obtained knowledge of fungi from their parents; $13 \%$ from their grandparents; $7 \%$ from traditional experience and less than $6 \%$ from other sources such as schools, health centers, at a location named "Valley of the Mushrooms"

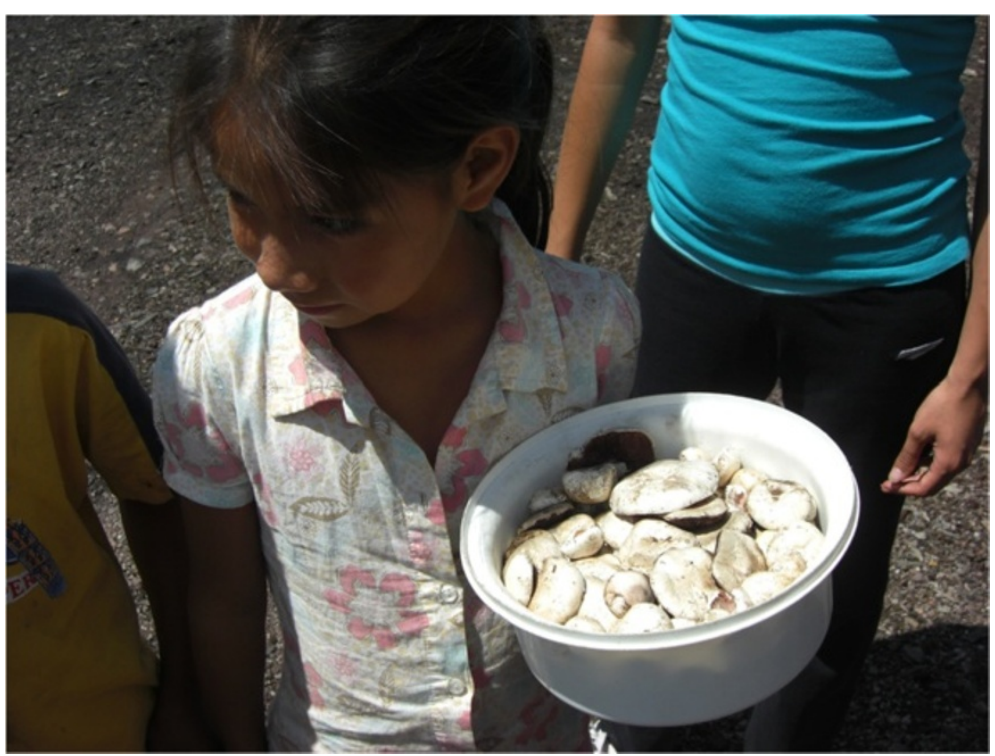

Figure 9 Children selling Agaricus campestris and Agaricus sp., in July along the road to San Juanito, Chihuahua. 


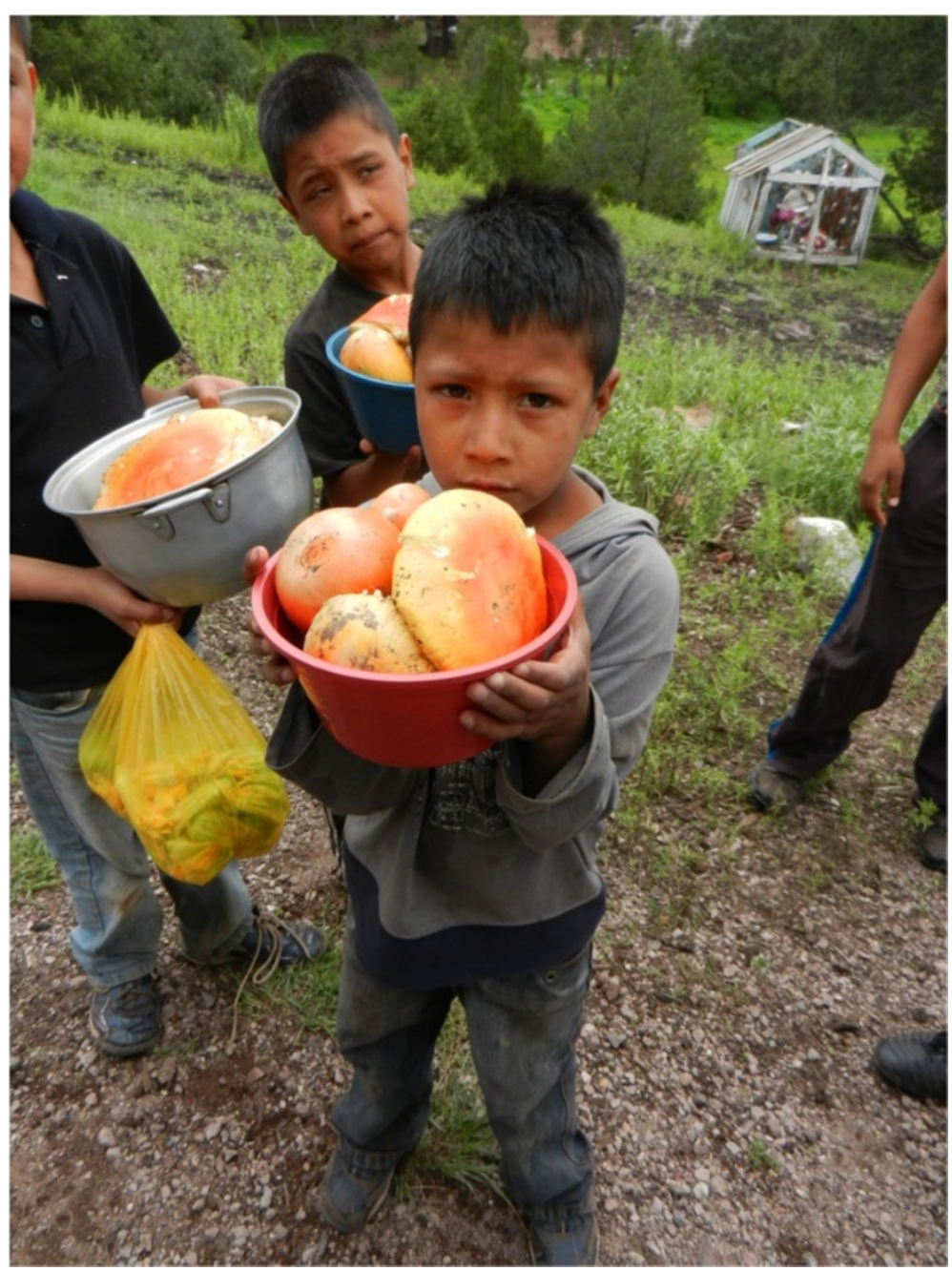

Figure 10 Children selling Amanita caesarea in the month of August along the road to San Juanito, Chihuahua.

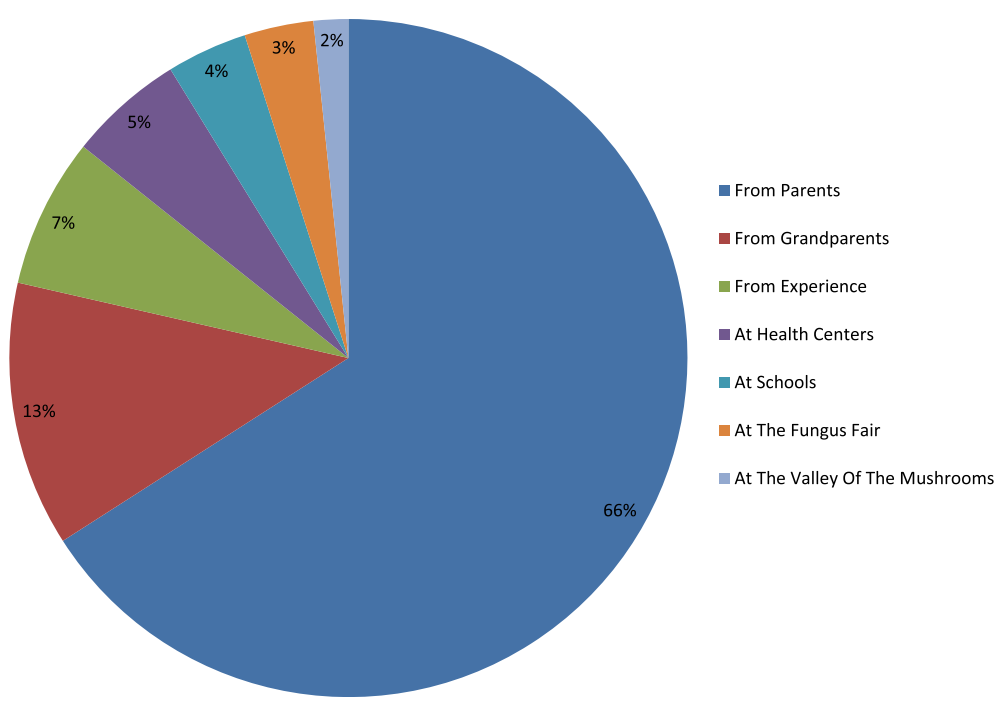

Figure 11 Teaching obtained knowledge of fungi. 
and at the annual Fungus Fair celebrated in San Juanito Chihuahua (Figure 11).

In other states of Mexico, such as Oaxaca and Chiapas, state fairs are organized on mushrooms to teach people and show them that wild mushrooms can be used as safe economic and food alternatives [33].

Based on feedback obtained from the reports of the children interviewed, in primary schools in the communities of Creel and San Juanito, teachers teach students how to distinguish edible mushrooms from poisonous species. This coincides with the studies by Moreno et al. [21] referring to textbooks for the fifth and sixth grades by the Ministry of Education (SEP) about fungi. The main features that people use to differentiate collected fungi are: appearance, color (e.g., red is bad, yellow at the top with white stem is bad, completely yellow is good), grains (flakes) or skirt (ring).

\section{Conclusions}

In the forests of the Sierra Tarahumara, there are records of around 450 species of fungi; 50 of them with edible importance at nationwide and apparently only 16 fungi species of those 50 are being consumed by the inhabitants of the municipalities of Bocoyna and Urique with Amanita caesarea complex being the most preferred by mestizos and Raramuris. We observed no apparent differences in the population studied in terms of gender, occupation, or language, regarding the recognition and consumption of species; however, this is not conclusive and so it is important to continue with a greater number of such studies to check whether this knowledge and use is differential.

There is no evidence that shows a meaningful comparison in terms of preferences for wild mushrooms, except for the naming of fungal species.

Many species considered as potentially edible in many regions of Mexico and around the world, such as Boletus edulis and Cantharellus cibarius, are not recognized as such by the mountain people of Chihuahua. There is a remarkable contrast between the high diversity of wildlife and the low use of species; while the population knows and appreciates three species in particular, they lack this attention for more than 20 species considered edible in most of Mexico. There is a possibility that they fear poisoning due to some casualties that occurred in the past before the Fungus Fair was established. This event was proposed specifically to generate knowledge in these locations on edible mushroom species. Likewise, there are species that might be used for medicinal purposes but there is no formal study on those used by the Raramuri people for healing; we therefore recommend specific future studies for these purposes.

Finally, in Chihuahua, ethno-mycological development depends largely on two factors: 1) Dissemination of knowledge to villagers, including mestizos and Raramuris, regarding differentiation, the appropriate use of edible wild species growing in the forests of the Sierra Tarahumara, and 2) joining together with professionals, authorities, and the community at large in the conservation on forest resources and thus promoting a more stable environment for the development of wild mushrooms.

\section{Additional file}

Additional file 1: Annex. Interview format.

\section{Competing interests}

The authors declare that they have no competing interests.

\section{Authors' contributions}

MQM designed the study, performed the field survey, prepared the draft manuscript, and concluded the final version this paper; FRS has enriched the document and performed much of the suggested corrections; IEAM organized the expedition and took part in the interviewing process in the field; FGO identified mushrooms and revised the manuscript; TLK identified the vegetation and revised the manuscript and PALM and IDEA participated in data collection and the interviewing process in the field. All authors read and approved the final manuscript.

\section{Acknowledgements}

The authors thank the FOMIX-CONACYT (CHIH-2011-C03-174148) for financial support of this research. We especially thank Violeta Chacon, Santos Anguiano Filio, Carlos Mario Perez, Tabita Rios, and Mario Astorga for their participation in the interviews and data gathering. Special thanks to Mario Perez and Marisa Ordaz Velazquez for language corrections in the manuscript.

\section{Author details}

${ }^{1}$ Instituto de Ciencias Biomédicas, Universidad Autónoma de Ciudad Juárez, Ciudad Juárez, Chihuahua, México. ${ }^{2}$ Facultad de Ciencias Biológicas,

Universidad de Ciencias y Artes de Chiapas, Tuxtla Gutiérrez, Chiapas, México. ${ }^{3}$ Facultad de Ciencias Forestales, Universidad Autónoma de Nuevo León, Linares, Nuevo León, México. ${ }^{4}$ Facultad de Zootecnia, Universidad Autónoma de Chihuahua, Chihuahua, Chihuahua, México.

Received: 14 September 2013 Accepted: 25 May 2014

Published: 17 September 2014

\section{References}

1. SEGOB: Secretaria de gobierno. Enciclopedia de los municipios de México. Instituto nacional para el federalismo y el desarrollo municipal. 2005, http://www.e-local.gob.mx/wb2/ELOCAL/EMM_chihuahua.

2. Verplancken LGSJ: Los Raramuris o Tarahumaras. In The Best of Mexico's Copper Canyon. Edited by Fisher RD. Tucson: Sunracer Publications; 2001

3. Pintado CAP: Tarahumaras. Pueblos indígenas del México contemporáneo. 2004, http://www.cdi.gob.mx.

4. Bennett WC, Zingg RM: Los Tarahumaras. Una tribu del Norte de México. México: Instituto Nacional Indigenista; 1986.

5. Armendáriz OR, Chacón JM: Caracterización de una plantación de Pinus arizonica Engelm, en el municipio de Bocoyna, Chihuahua. In Folleto Técnico, Cd. Madera, Chihuahua, México: Instituto Nacional de Investigaciones Forestales, Agrícolas y Pecuarias. Centro de Investigación Regional del Norte, Campo Experimental Madera; 1999.

6. Brambila DSJ: Diccionario raramuri-castellano (Tarahumara). México: Obra Nacional de la buena Prensa; 1976.

7. Barragán PG: Análisis de la Estructura, Clasificación y Potencial Natural de los Bosques Templados en Bocoyna, Chihuahua. In PhD. Thesis. Facultad de Zootecnia. Chihuahua, Mexico: Universidad Autónoma de Chihuahua; 2006.

8. Farías MA, Aranda GH: Estudio básico de comunidad. Ejido San Ignacio de Arareco. Facultad de Zootecnia y Ecología. Mexico: Universidad Autónoma de Chihuahua; 2008. 
9. Quiñonez MM, Garza OF: Taxonomía, ecología y distribución de hongos de Bosque Modelo, Chihuahua. Ciencia en la Frontera 2003, 2(1):63-69.

10. Quiñonez MM, Garza OF, Vargas M: Aspectos ecológicos y diversidad de hongos ectomicorrizicos en bosque de pino y encino de 5 localidades del Municipio de Bocoyna, Chihuahua. Ciencia en la Frontera 2005, 3(1):29-38.

11. Quiñonez MM, Garza OF, Mendoza FJR, García JJ, Sáenz AJ, Bolaños HR: Guía de Hongos de la región de Bosque Modelo Chihuahua. Facultad de Zootecnia. Mexico: Universidad Autónoma de Chihuahua; 1999.

12. Boa E: Los Hongos Silvestres Comestibles. Perspectiva Global de su uso e Importancia Para la Población. Roma, Italia: FAO; 2005

13. Pegler DN: Useful fungi of the world: caesar's mushroom and the christmas mushroom. Mycologist 2002, 16(4):140-141. United Kingdom: Cambridge University Press.

14. Dijk HV, Onguene NA, Kuyper TW: Knowledge and utilization of edible mushrooms by local population of the rain forest of South Cameroon. Ambio 2003, 32(1):19-23.

15. Sánchez JE, Mata G: Hongos Comestibles y Medicinales en Iberoamérica. Tapachula, Chiapas: El Colegio de la Frontera Sur; 2012.

16. Garibay-Orijel R, Cifuentes J, Estrada-Torres A, Caballero J: People using macro-fungal diversity in Oaxaca. Fungal Divers 2006, 21:41-67.

17. Pérez-Silva E, Aguirre-Acosta E: Flora micológica del estado de Chihuahua, México. I Inst Biología 1986, 57:17-32.

18. Laferriere EJ, Gilbertson RL: Fungi of Nabogame, Chihuahua, México. Mycotaxon 1992, 44:73-87.

19. Moreno-Fuentes A, Aguirre-Acosta E, Villegas M, Cifuentes J: Estudio fungistico de los macromicetos en el municipio de Bocoyna, Chihuahua, México. Revista Mexicana de Micología 1994, 10:63-76.

20. Díaz-Moreno R, Valenzuela R, Marmolejo JG, Aguirre-Acosta E: Hongos degradadores de la Madera en el estado de Chihuahua, México. Revista Mexicana de Biodiversidad 2009, 80(1):13-22.

21. Moreno-Fuentes A, Aguirre-Acosta E, Pérez-Ramírez L: Conocimiento tradicional y científico de los hongos en el estado de Chihuahua, México. Etnobiología 2004, 4:89-105.

22. Mares A: Ralamuli Nu'tugala Go'ame. Chihuahua: Comida de los Tarahumaras. Don Burgess, McGuire; 1982

23. Lumholtz C: Unknow México I. New York: Charles. New York Scribner's Sons; 1902

24. Moreno-Fuentes A, Cifuentes J, Bye R, Valenzuela R: Kute-mo'ko-a: un hongo comestible de los indios rarámuri de México. Revista Mexicana de Micología 1996, 12:31-39.

25. Moreno-Fuentes A: Estudio Etnomicológico Comparativo Entre Comunidades Raramuris de la Alta Tarahumara. Chihuahua, México. In PhD Thesis. Facultad de Ciencias. Edited by. México, D.F.: Universidad Autónoma de México: 2002.

26. Quiñonez-Martínez M, Garza-Ocañas F, Anguiano-Filio S, Chacón-Ramos V, Bernal-Carrillo S: Diversidad de hongos comestibles en los bosques de Bocoyna y Urique, del estado de Chihuahua. Ciencia en la Frontera 2010 3(1):29-34.

27. Arora D: All That the Rain Promises and More, A hip pocket Guide to Western Mushrooms. United States: Ten Speed Press; 1991.

28. Bessette AE, Bessette AR, Fisher DW: Mushrooms of Northeastern North America. USA: Syracuse University Press; 1997.

29. Fisher DW, Bessette AE: Edible Wild Mushrooms of North America. A Field to Kitchen Guide. USA: University of Texas Press; 1992.

30. Montoya A, Kong A, Estrada-Torres A, Cifuentes J, Caballero J: Useful wild fungi of La Malinche national park. Fungal Divers 2004, 17:115-143.

31. Sheppard GH, Arora D, Lampman A: The grace of the flood: classification and use of wild mushrooms among the highland Maya of Chiapas. Econ Bot 2008, 62(3):207-212.

32. Acevedo LG: Fallece Envenenado con Hongos. México: El Diario de Chihuahua; 1999.

33. Ruan-Soto F, Mariaca R, Alvarado R: Intoxicaciones mortales por consumo de hongos silvestres: una cadena de errores. Ecofronteras 2012. 44:12-14.

34. Bolaños RH: Manual del Bosque. Sierra Tarahumara, Región San Juanito-Creel. Mexico: Bosque Modelo Chihuahua; 1996.

35. Instituto Nacional de Estadística y Geografía: 2013, http://www.inegi.org.mx.

36. Quiñonez MM, Lavín MP, Garza OF, De La Mora CA, Lebgue KT, Woocay PA: Riqueza y Frecuencia de Hongos Ectomicorrizogenos en el Municipio de Urique, Chihuahua, México. Ciencia en la Frontera 2009, 7(2):39-46.
37. Vargas Medrano M: Estudio Taxonómico de hongos macromicetos en la localidad de Cuiteco, Municipio de Urique, Chihuahua, México. In BS thesis. Edited by Instituto de Ciencias Biomédicas. Mexico: Universidad Autónoma de Ciudad Juárez; 2004.

38. Secretaria de Desarrollo Comercial y Turístico del Estado de Chihuahua: México desconocido Así es Chihuahua. Guía especial. IASA Comunicación; 2010.

39. Bernard R: Research Methods in Anthropology. Walnut Creek, California: Altamira Press; 1995

40. Thomas E, Vanderbroek I, Van Damme P: What works in the field? A comparison of different interviewing methods in ethnobotany with special reference to the use of photographs. Econ Bot 2007, 61(4):376-384

41. Cifuentes J, Villegas M, Pérez Ramírez J: Hongos. Manual del Herbario. México: Consejo Nacional de la Flora de México A.C; 1986.

42. Largent D, Johnson D, Watling R: How to identify mushrooms to genus. III. Microscopic Features. USA: Mad River Eureka; 1977.

43. Sandoval C: Investigación Cualitativa. Programa de Especialización Teórica, Métodos y Técnicas de Investigación Social. Bogotá: ICFES; 2002

44. Ruan-Soto F: 50 años de Etnomicología en México. LACANDONIA Revista de Ciencias de la Universidad de Ciencias y Artes de Chiapas 2007, 1:97-108.

45. Garibay-Orijel R, Caballero J, Estrada-Torres A, Cifuentes J: Understanding cultural significance, the edible mushrooms case. J Ethnobiol Ethnomedicine 2007, 3(4):1-18.

46. Grajales-Vásquez A, Velasco-Alvarado RK, Sánchez-Molina DY, Reyes-Mérida IY, Serrano-Ramírez JL, Ruan-Soto F: Estudio etnomicológico en San Antonio Linda Vista, Municipio de La Independencia, Chiapas. Lacandonia 2008 , 2(2):5-15.

47. Ruan-Soto F, Cifuentes J, Mariaca R, Limón F, Pérez-Ramírez L, Sierra S: Uso y Manejo de Hongos Silvestres en dos comunidades de la Selva Lacandona, Chiapas, México. Revista Mexicana de Micología 2009, 29:61-72.

48. Garza F, Quiñónez M, Chacón V, Garza L, Carrillo Q, Cázares E: Sustainable management of edible forest mushrooms in Chihuahua, Mexico. Actes du Colloque International Champignons forestiers Comestibles a Potentiel Commercial. Québec, Canadá: Université Laval; 2009.

49. Ruan-Soto F: Micofilia o Micofobia: Estudio comparativo de la importancia cultural de los hongos comestibles entre grupos mayas de tierras altas y de tierras bajas de Chiapas, México. In PhD Thesis. Edited by Instituto de Biología. México: Universidad Nacional Autónoma de México; 2014.

50. Guzmán G: Las intoxicaciones producidas por los hongos. Ciencia y Desarrollo 1980, 32(6):129.

51. Rivas MV: En marcha la feria del hongo de San Juanito, Chihuahua. 2011, http://www.oem.com.mx/elheraldodechihuahua/notas/n2184806.htm.

52. Ortiz VH: El Valle de los hongos en Chihuahua. El Informador.com. 2009, http://www.informador.com.mx/suplementos/2009/105729/6/valle-de-loshongos-en-chihuahua.htm.

doi:10.1186/1746-4269-10-67

Cite this article as: Quiñónez-Martínez et al:: Knowledge and use of edible mushrooms in two municipalities of the Sierra Tarahumara, Chihuahua, Mexico. Journal of Ethnobiology and Ethnomedicine 2014 10:67.

\section{Submit your next manuscript to BioMed Central and take full advantage of:}

- Convenient online submission

- Thorough peer review

- No space constraints or color figure charges

- Immediate publication on acceptance

- Inclusion in PubMed, CAS, Scopus and Google Scholar

- Research which is freely available for redistribution 